Canadian Journal of Higher Education

Revue canadienne d'enseignement supérieur

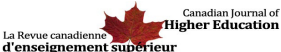

\title{
Book Review of "The Great Mistake: How We Wrecked Public Universities and How We Can Fix Them"
}

\section{Michael D. Buzzelli and Sean Quigley}

Volume 49, Number 1, 2019

URI: https://id.erudit.org/iderudit/1060831ar

DOI: https://doi.org/10.7202/1060831ar

See table of contents

Publisher(s)

Canadian Society for the Study of Higher Education

ISSN

2293-6602 (digital)

Explore this journal

Cite this review

Buzzelli, M. \& Quigley, S. (2019). Review of [Book Review of "The Great Mistake: How We Wrecked Public Universities and How We Can Fix Them"]. Canadian Journal of Higher Education / Revue canadienne d'enseignement supérieur, 49(1), 179-181. https://doi.org/10.7202/1060831ar 


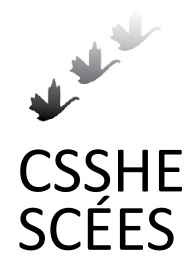

Canadian Journal of Higher Education Revue canadienne d'enseignement supérieur

Volume 49, No. 1, 2019, pages 179 - 181

\section{Book Review / Compte rendu}

\section{Newfield, Christopher (2016). The Great Mistake: How We Wrecked Pub- lic Universities and How We Can Fix Them. Baltimore: Johns Hopkins Uni- versity Press. Pages: 448. Price: 32.95 USD (paper).}

Reviewed by Michael Buzzelli, Associate Professor, The University of Western Ontario and Sean Quigley, Independent Scholar.

Review dialogue by two colleagues.

Quigley: Thanks for sharing The great mistake by Professor Christopher Newfield of U.C. Santa Barbara. Newfield's book is a worthwhile read. He argues that a cycle of devolution based upon reduced funding and the encroachment of private interests and revenue are eroding the nature and role of the public university. I agree. It seems to create an identity crisis for publicly funded universities which, strangely, Newfield perpetuates to a degree. He makes the case that lower, or no tuition at universities leads to greater access and thereby overall economic productivity gains and growth. This leads me to ask: Is the point of education strictly about employment for graduates? Economic prosperity?

Buzzelli: You've really cut to the chase. I'm glad you found the book thought-provoking. Yes, I think you've got the premise nailed. Mostly. Newfield sees the long-term benefits of greater access (via more public funding and reduced tuition) and improved teaching and learning as the avenue to economic gains: a virtuous circle returning greater public investment and so forth. But maybe Newfield feels the American reader needs to see productivity gains and economic benefits to justify public investment. After all, he does write (pp. 7-13, 17) that his intended audience is the college-aged American family. Would Canadians need the same justification or are we more convinced of the benefits of the public good our universities bring in and of themselves?

Quigley: The point the author makes (pp. 24-26, 140) about the spending arms race on facilities and buildings is important. It is classic mission drift. Here in Canada, and in our home town, London, we have seen huge investment in student residences and recreation buildings, yet teaching assistants across Ontario have taken labour action due to low pay. The London Free Press reported that "more than half of teaching assistants at Western have a net income of less than $\$ 11,000$ " (Daniszewski, 2018, April 13). Resource growth is seen in areas that some say are not core to the mission (i.e., teaching and learning) (Sher, 2018). So let me answer your question about ROI. If the return on investment is only so 
a student can be guaranteed a job, then universities become places of transaction: an extension of the marketplace and subject to the same forces of scarcity and competition. Resources can and do get allocated to the wrong things. The author makes, wrongly I believe, the point that universities are to a large extent about work and in order to increase productivity we need lower barriers to university access. This may have been so in earlier postwar decades, as Trow has famously described (see Burrage, 2010) but the focus then was much more on building the core mission.

Buzzelli: I think we're being a bit too harsh on Newfield. And maybe a little too "black or white" too. Yes, Newfield does ultimately rest his argument on a ROI foundation-a strange premise since the book is an appeal for public universities to be a fixture of our social architecture. This reminds me of Kerr's (2001) foundational treatment of (American) university studies. Even of Fallis' (2007) treatment here in Canada. Still, even if you disagree with the ROI rationale, universities confer status in granting credentials and that is how many -including his targeted college-aged American family-see tertiary education.

Quigley: Yes, the university does grant status by bestowing degrees. The role of universities has changed to that of a place that, if successful, you have a higher chance of getting a job once your degree is complete. Some of these issues are driven by the changing nature of the economy since the 1950s. Newfield makes the case that publicly funded universities are good for the economy. It is an important point and one with which many will agree. But the argument could have been more developed around the teaching and learning mission. It is not enough merely for our universities to be publicly funded but to be publicly funded on credentialing people who can learn. This bears more explicit treatment: at the very least on par with an economics, jobs and productivity rationale. I make this point because a number of CEOs were asked what they most want in new employees. A common theme emerges, summed up in this quote by Tim Ryan, who is the Chairman and Senior Partner at Price Waterhouse Coopers in the US. He said:

We want people with the emotional intelligence and creativity to be successful in a world that is moving fast. We need people who can lead themselves and others, and who have an open and inclusive mindset so they can bring together diverse teams to get to best solutions to the challenges facing our clients and our world. (Entis, 2017).

Buzzelli: I agree. Still, I'm troubled by another apparent blind spot in the book: that institutional culture and status are increasingly driven by research and related outputs. Teaching and learning often take a back seat. This layers on top of the funding issues Newfield focuses on. You can see this status pursued and reinforced in the various university rankings, including Canada's Mclean's annual scorecard. In fact, there is a growing call for more research supports, funding and outputs among community colleges, whose mandate was only ever teaching and learning. If Newfield's argument has any value in Canada, it will have to confront this cultural brick wall. Quest University in BC seems to have it right: Its focus is clearly on teaching and learning quality. But it is private. This would seem to be the opposite of what Newfield wants.

Quigley: Yes, I am hoping for cultural change. A focus on research may be a stumbling block for an appeal to greater public funding for teaching and learning outcomes. But in relying on an economic rationale, Newfield could have developed teaching-related argu- 
ments more fully. For example, one could argue that pedagogy needs to reflect an increasingly complex labour market. Like a complex adaptive system (Stockholmresilience.org, 2018), the labour market is changing rapidly in new and different ways and this makes the genuinely prepared student better able to adapt and succeed. In Newfield's proposed recovery cycle (part 3 of the book), he identifies what he calls quality mass instruction and aggregate learning (p. 314) but I think the reader may be left wanting more. Consider that nearly 300 pages of the book are devoted to the cycle of decline but only the next 40 pages to the cycle of recovery. His target audience would almost certainly want to read more about solutions and next steps. But having said that, Newfield's book is well worth the read by the informed public and scholars alike.

\section{References}

Burrage, M. (Ed.) (2010). Martin Trow: Twentieth century higher education: From elite to mass to universal. Baltimore: Johns Hopkins University Press.

Daniszewski, H. (2018, April 13). Western University teaching assistants back off strike threat. London Free Press, http://lfpress.com/news/local-news/western-teachingassistants-reject-offer-amid-strike-threat.

Entis, Laura. (2017, March). Here's what makes the perfect job candidate - According to 10 CEOs. Fortune. Retrieved from fortune.com/2017/o3/26/ceos-ideal-job-candidates/.

Kerr, C. (2001). The uses of the university ( $5^{\text {th }}$ ed.). Cambridge, Mass.: Harvard University Press.

Fallis, G. (2007). Multiversities, ideas and democracy. Toronto, ON: University of Toronto Press.

Sher, J. (2018, May 1). Western University teaching assistants back off strike threat. London Free Press. Retrieved from http://lfpress.com/news/local-news/westernfaculty-opposes-big-boost-to-senior-exec-pay

Stockholmresilience.org. (2018). Complex Adaptive Systems - Stockholm Resilience Centre. [online] Retrieved from http://www.stockholmresilience.org/research/researchstreames/complex-adaptive-systems.html. 